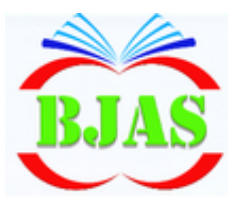

Available online at http://bajas.edu.iq

https://doi.org/10.37077/25200860.2019.255

College of Agriculture, University of Basrah

ISSN $1814-5868$

Basrah J. Agric. Sci., 32(Spec. Issue 2): 35-44, 2019

\title{
Effect of Plant Residues-Treated Urea on Growth and N-Uptake of Wheat
} (Triticum aestivum L.)

\author{
Israa A.Y. Al-Malaky \& Mohammed A. Abdulkareem
}

Department of Soil Sciences \& Water Resources, College of Agriculture, University of Basrah, Iraq

*Corresponding author e-mail: israaaaa70@gmail.com

Received 19 September 2019; Accepted 18 November 2019; Available online 22 November 2019

\begin{abstract}
A pot experiment was carried out to study the effect of the urea fertilizer treated with corn or conocarpus residues on growth and $\mathrm{N}$ uptake of wheat plant. Three kilograms of dry soil (Silt clay loam) were placed in a plastic pots and four levels of nitrogen $\left(0,60,120\right.$ and $\left.180 \mathrm{~kg} \mathrm{~N} \mathrm{ha}^{-1}\right)$ were added as urea. Urea was treated with one of the following methods : mix with the conocarpus leaves powder at rate of $4 \%$ of dry soil weight, mix with the conocarpus roots powder at rate of $4 \%$ of dry soil weight dissolved in, aqueous extract of the corn root at rate of $1 / 4$ of the field capacity ,or coated with dried aqueos extract of corn root at ratio of $10 \%$ of urea weight. Treatment included urea treated with the standard chemical inhibitor (PMA) was used. shoot dry weight, $\mathrm{N}$ conc., $\mathrm{N}$-uptake and $\mathrm{N}$ recovery were obtained. The results showed that treatment of urea fertilizer with water extract or coated with corn root extract resulted in improved growth parameters as compared with a PMA and control treatments .However ,treating urea with leaves or root powders decreased plant growth parameters .Urea coated with $10 \%$ dried extract of corn roots gave the highest dry matter of $3.06 \mathrm{~g} \mathrm{pot}^{-1}$ and nitrogen uptake of $69.90 \mathrm{mg} \mathrm{pot}^{-1}$ resulting in saving of $60 \mathrm{~kg} \mathrm{~N} \mathrm{ha}{ }^{-1}$ to give the same results for control and PMA treatments.
\end{abstract}

Key words : Wheat, Corn Residue, Conocarpus Residue, Dry Matter ,N-Uptake.

\section{Introduction}

The production of cereals in the world is about 24988 million tons in 2014 .The share of wheat production is 707200000 tons, this consumed about 113100000 tons of nitrogen fertilizer which_are expected to rise to 119400000 tons in 2018 with annual increase of $1.4 \%$ (FAO, 2015). Zhu \& Chen (2002) reported that urea is one of the most solid nitrogen fertilizers consumed worldwide (more than $50 \%$ of total nitrogen fertilizers) due to its high $\mathrm{N}$ content (46\%), low manufacturing cost, easy storage and handling. However, the rapid hydrolysis of-
$\mathrm{NH}_{2}$ containing urea by urease leads to several problems including losses (volatilization, leaching and denitrification), toxicity of seeds and seedling when added in high doses, as well as possible contamination of water, air and soil (Trenkel, 2010). One of the important approaches to minimize $\mathrm{N}$ losses from urea and reduce the toxicity and pollution hence, rise urea fertilizer efficiency is using compounds inhibit urease activity in soil and delay urea hydrolysis. Numbers of chemical and organic compounds are available as urease inhibitors. 
The damage caused by use of chemical inhibitors, as well as its high cost of manufacturing despite of their high efficiency at low concentrations, prompted the interested to search for alternative natural materials as urease inhibitors. The great challenge is to find natural substances with good properties that are nontoxic ,effective at low concentrations ,chemically stable when mixed with urea and urea solutions, highly degraded in soil and with competitive costs (Trenkel, 2010). Many plant residues have been tested as urease inhibitors in soil and have succeeded in reducing urea hydrolysis, reducing nitrogen loss and improving plant growth (Sivapalan et al., 1983; Abdulkareem, 2006; Mohanty et al., 2008; Patra et al., 2009; Yaseen, 2010; Hoshan, 2012; Zhao et al., 2015; Mathialagan et al., 2017). The inhibitory effect of plant residues or plant extracts depends on the amount, quality of active substances in the plant and extraction methods.

Aqueous extracts of Rhaza stricta ,Myrtus leaves, Eucalyptus leaves, date palm fibre and sunflower inhibited urease when applied with urea and have been positive effect on the growth and yield of wheat, grass, radish and barley (Al-Mutlaq et al., 2001; Abdulkareem, 2006; Naseem et al., 2009). Results of Singh \& Singh (1989) and Kiran \& Patra (2002) showed that coating urea with neem oil ,mint oil, mint essential oil and mint terpenes resulted in a significant increases of growth, yield and N-uptake of wheat as compared with uncoated urea. The results of Al-Douri \& Mohammad (2014) indicated that the presence of corn residues in the field at the level of 6 tons $\mathrm{ha}^{-1}$ has improved the growth of wheat planted after maize, but increasing the level to 9 tons ha ${ }^{-1}$ reduced plant dry weight to about $25 \%$.
In previous study, a laboratory experiment was carried out at the College of Agriculture, Basrah University to study the effect of urea treated with leaves or root of corn (Zea mays L.) or conocarpus (Conocarpus lancifolius Engl) at different methods on activity of urease in calcareous soil (Al-Malaky \& Abdulkareem, 2018). In present study the following treatments of urea that caused the highest inhibition of urease enzyme in soil were selected to study their effect on growth of wheat:

1. Conocarpus leaves powder mixed with urea and add at level of $4 \%$ based on soil dry weight.

2. Conocarpus roots powder mixed with urea and add at level of $4 \%$ based on soil dry weight.

3. Urea dissolved in aqueous extract of corn roots and added at level of 1/4 of soil field capacity

4. urea coated with dried aqueous extract of corn roots at ratio of $10 \%$ of urea weight and mix with soil .

\section{Materials \& Methods}

Corn roots were collected in July and conocarpus residues (leaves and roots) were collected in April, cleaned, air-dried ,grinded, sieved then treated urea at the following methods:

1-Concarpus leaves powder was mixing with soil at rate of $4 \%$ based on soil dry weight, then urea added to the mixture at rate of 500 $\mathrm{mg} \mathrm{N} . \mathrm{kg}^{-1}$ soil.

2-Concarpus roots powder was mixing with soil at rate of $4 \%$ based on soil dry weight, then urea added to the mixture at rate of 500 mg N. kg-1 soil.

3-Aqueous extraction of corn root residues was prepared by mixing the residues with 
Al-Malaky \& Abdulkareem/ Basrah J. Agric. Sci., 32(Spec. Issue 2): 35-44, 2019

distilled water at ratio of 1:10 (residue :water), shaking for $6 \mathrm{hrs}$. at $160 \mathrm{rpm}$ then filtered. Urea at rate of $500 \mathrm{mg} \mathrm{N}$. kg-1 soil was dissolved in the prepared extract and added to soil equivalent to $1 / 4$ of field capacity.

4-The extract prepared in method (3) was dried at $40 \mathrm{C}$. Urea at rate of $500 \mathrm{mg} \mathrm{N} \mathrm{kg}^{-1}$ soil was treated with castor oil at rate of $1 \%$ overnight then coated manually by the dried extract at ratio of $10 \%$ of urea rate.

The soil (Typic Torrifluvents) used in this study was collected from Al-Deir region, north of Basrah province at a depth of 0-30 $\mathrm{cm}$. Soil properties determined according to methods described by Black (1965) and Page et al. (1982) and presented in table (1). Three kilograms of air-dried soil was placed in plastic pot and treated with four levels of urea $\left(0,60,120\right.$ and $\left.180 \mathrm{~kg} \mathrm{ha}^{-1}\right)$ with mentioned methods or coated with phenyl mercuric acetate (PMA) at ratio of $10 \%$ of Urea or untreated (control) .Pots were placed in greenhouse and wheat seeds (variety Ebaa 99) were shown in Nov.16, 2017. All the pots received $120 \mathrm{~kg} \mathrm{ha}^{-1}$ of $\mathrm{P}_{2} \mathrm{O}_{5}$ and $\mathrm{K}_{2} \mathrm{O}$

Table (1): General characteristics of soil used.

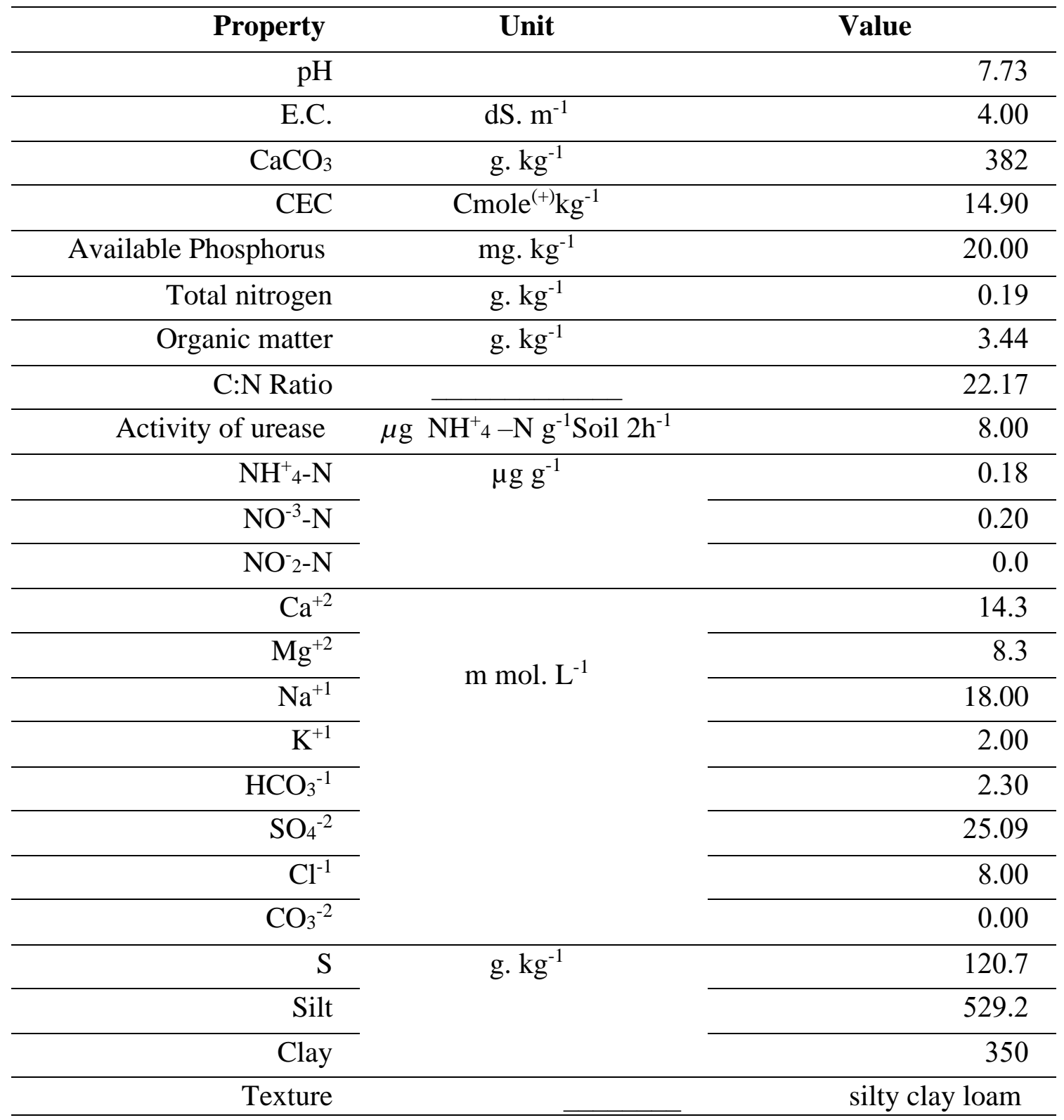


as triple superphosphate and potassium sulfate, respectively. All fertilizers were applied by mixing at the time of sowing. Soil moisture was maintained at field capacity by periodic weight and compensated by the addition of water all over the experiment period. The statistical design followed a completely randomize design (CRD) with three replicates. After 60 days of sowing the plant were harvested from soil surface and dry weight was measured. Nitrogen in plant shoot was determined by digestion with salicylic acid- $\mathrm{H}_{2} \mathrm{SO}_{4}$ mixture that described by Nelson \& Sommers (1973), then the digest was analyzed by the Kjeldahl distillation method (Bremner, 1982). Uptake and recovery of $\mathrm{N}$ were calculated as the following :

$$
\mathrm{N}-\text { uptake }=\text { dry weight } \times \mathrm{N} \text { concentration in shoot }
$$

$\mathrm{N}-$ recovery $\%=\frac{\mathrm{N} \text { uptake from treatment }-\mathrm{N} \text { uptake from control }}{\text { Amount of } \mathrm{N} \text { applied }} \times 100$

All observations were subjected to the analysis of variance (ANOVA) by using SPSS V.14 program. The Revised least significant difference were calculated at $5 \%$ level for significant " $F$ " test .

\section{Results \& Discussion:}

\section{Shoot dry weight :}

The results of table (2) showed a significant increases in dry matter of wheat plant when urea treated with corn residues (Aqueous extract of corn root and coated urea) as compared with the untreated urea, with an increase per cents of 52 and $54 \%$ respectively, with no significant difference between them. These increases in dry matter attributed to reduce urea hydrolysis (AlMalaky \& Abdulkareem, 2018) and decrease the ammonia volatilization of fertilizer, which increased the amount of available nitrogen in soil and affect the dry weight of the plant positively. This result was similar to that of Abdulkareem (2006), Yassin (2010) and Hoshan (2012) who obtained an increase in the dry matter of barley and maize when urea treated with aqueous extracts or coating with secondary metabolites of some plants.
Nitrogen plays an important role in the formation of chlorophyll, proteins and enzymes, and stimulates the production of oxin, which promotes cell division and proliferation, thereby increasing plant biomass and reversing the dry weight of the vegetative part (Barker \& Bryson, 2007).

On the other hand, there are no significant differences at urea treated with conocarpus leaves or root as compared with untreated urea (table 2). Although, these two treatments caused higher inhibition of urease (Al-Malaky \& Abdulkareem, 2018) and minimizing $\mathrm{NH}_{3}$ volatilization, the negative effect on plant growth may attributed to direct effects of allelopathic substances, especially phenols derived from the decomposition of the powder and /or to indirect effects resulting from a defect in fertility of soil. Rice (1984) attributed the negative effect of plant extracts to the role of allelopathic compounds, especially phenols, in inhibiting the construction of porphyrin, compound responsible for the formation of chlorophyll. Cheng \& Cheng (2015) also noted that plantderived chemicals increase water stress and reduce water absorption by plant, as well as the inhibition of the ATPase co-enzyme 
Al-Malaky \& Abdulkareem/ Basrah J. Agric. Sci., 32(Spec. Issue 2): 35-44, 2019

Table(2): Effect of the methods of urea treatment on shoot dry weight of wheat plant $\left(\mathrm{g} \mathrm{pot}^{-1}\right)$.

\begin{tabular}{|c|c|c|c|c|c|}
\hline \multirow[b]{2}{*}{ Treatment } & \multicolumn{4}{|c|}{ Urea level $\left(\mathrm{kg} \mathrm{N} \mathrm{ha}^{-1}\right)$} & \multirow[b]{2}{*}{ Mean } \\
\hline & 0 & 60 & 120 & 180 & \\
\hline Conocarpus leaves Powder & 0.75 & 1.87 & 2.24 & 2.33 & 1.79 \\
\hline Conocarpus root powder & 0.75 & 2.00 & 3.00 & 2.73 & 2.12 \\
\hline Aqueous extract of corn roots & 0.96 & 2.60 & 3.69 & 4.81 & 3.02 \\
\hline Coated urea & 0.55 & 2.55 & 3.76 & 5.36 & 3.06 \\
\hline PMA & 1.10 & 2.00 & 3.06 & 0.53 & 1.67 \\
\hline Control & 0.80 & 2.06 & 1.82 & 3.30 & 1.99 \\
\hline Mean & 0.81 & 2.18 & 2.92 & 3.18 & \\
\hline treatment $=1.02$ & level $=0.68$ & treatn & nt $x$ le & ns & \\
\hline
\end{tabular}

which responsible for increasing the $\mathrm{K}^{+} / \mathrm{Na}$ ${ }^{+}$ratio in the plant tissue by controlling the permeability of these ions through plasmalema. All the urea treatments increased plant dry matter in comparison to PAM treatment (table 2), with more pronounced at treatments of aqueous extract and coated urea. Furthermore, untreated urea had higher dry matter as compared with PMA treatment.

The results were similar to those of Yassin (2010), Neghamish (2012) and Hoshan (2012) who obtained an increase of dry matter weight of maize, sorghum and barley when urea treating with water extracts or coating with secondary metabolites of some plants compared to chemical inhibitors such as HQ and ATS. This is due to the negative effect of PMA on plant growth, which is most pronounced at the high nitrogen level (table 2).That means the increasing of PMA as a result of increasing the level of urea will increased its negative effect on plant. Joo et al. (1992) pointed out that some chemical inhibitors (ATS and NBPT) inhibit enzyme activity only when added at high levels, resulting in a negative effect on plant growth. Trenkel (2010) confirmed this when he pointed out that one of the determinants of the use of the hydorquinone is its high toxicity to the organisms. PMA $\left(\mathrm{C}_{8} \mathrm{H}_{8} \mathrm{HgO}_{2}\right)$ is a chemical compound containing mercury, which usually used to stabilize dyes. When PMA added to the leaves of plant, it is considered to be an inhibitory agent for transpiration because it alters the permeability of the guard cells and their functions. It is also used as an inhibitor for bacteria and fungus. In our study, increasing the addition of PMA at high levels of urea associated with increasing the amounts of mercury and phenol and may lead to a direct inhibitory effect on wheat plant the results of table (2) indicated that there was an increase in the dry matter of wheat plant with increasing the level of nitrogen the dry matter were $0.81,2.18,2.92$ and $3.18 \mathrm{~g} \mathrm{pot}^{-1}$, for levels of $0,60,120$ and $180 \mathrm{~kg} \mathrm{~N} \mathrm{ha}^{-1}$, respectively. The differences were significant between the three levels of urea and the control, as well as between the levels of 60 and $120 \mathrm{~kg} \mathrm{~N}^{-1}$. This finding is similar to Eltelib et al. (2006), Babalar et al.(2010) and Selim et al. ( 2010). Although there is no significant effect of the interaction of treatment and $\mathrm{N}$ levels (table 2); it is noticed that treating urea with root or leaves of conocarpus gave the lowest dry matter at all levels of nitrogen, which confirms the negative role of the high addition of these 
powders. The results of the interaction also showed an increase in dry matter by increasing the level of nitrogen up to $120 \mathrm{~kg}$ $\mathrm{N} \mathrm{ha}^{-1}$ at the treatment of PMA, while the dry matter decreased significantly to $0.53 \mathrm{~g} \mathrm{pot}^{-1}$ at level of $180 \mathrm{~kg} \mathrm{~N} \mathrm{ha}^{-1}$.

\section{Nitrogen concentration in shoot of wheat plant}

Table (3) shows that higher $\mathrm{N}$ concentrations were obtained in plant received urea treated with aqueous extract or coated with dry aqueous extract as compared with plant received untreated urea, with significant increase at coated urea. This is may be due to reduced ammonia volatilization and sufficient nitrogen uptake by the plant. Abdulkareem (2006) reported that treated urea with some plant extracts significantly reduce ammonia volatilization .However, other treatments gave lower $\mathrm{N}$ concentration as compared with untreated urea. Except that of conocarpus root powder treatment, all urea treatments gave higher $\mathrm{N}$ concentration in plant as compared with PMA treatment (table 3). Coating urea with dried aqueous extract had a significant increase with a percent of $17 \%$ as compared with PMA treatment having a same trend of dry matter (table 2). This result is in accord with that of Negamish (2012) who reported a superiority of the treatment of urea treated with aqueous extracts over chemical inhibitors (HQ and ATS) in the concentration of nitrogen in sorghum leaves. Except that of conocarpus root powder treatment, all urea treatments gave higher $\mathrm{N}$ concentration in plant as compared with PMA treatment (table 3). Coating urea with dried aqueous extract had a significant increase with a percent of $17 \%$ as compared with PMA treatment having a same trend of dry matter (table 2). This result is in accord with that of Negamish (2012) who reported a superiority of the treatment of urea treated with aqueous extracts over chemical inhibitors (HQ and ATS) in the concentration of nitrogen in sorghum leaves.

The results of table (3) displayed a significant increase in concentration of nitrogen in leaves with an increasing rate of nitrogen. The differences were significant among all nitrogen rates, except for

Table (3): Effect of the methods of urea treatment on nitrogen concentration in shoot of wheat plant ( $\mathrm{g} \mathrm{kg}^{-1}$ dry matter).

\begin{tabular}{|c|c|c|c|c|c|}
\hline \multirow[t]{2}{*}{ Treatment } & \multicolumn{4}{|c|}{ Urea level $\left(\mathrm{kg} \mathrm{N} \mathrm{ha}^{-1}\right)$} & \multirow[t]{2}{*}{ Mean } \\
\hline & 0 & 60 & 120 & 180 & \\
\hline Conocarpus leaves Powder & 10.46 & 18.89 & 20.47 & 22.03 & 17.96 \\
\hline Conocarpus root powder & 7.87 & 18.02 & 21.00 & 20.43 & 16.83 \\
\hline Aqueous extract of corn roots & 11.88 & 18.20 & 22.00 & 23.93 & 18.95 \\
\hline Coated urea & 11.02 & 25.88 & 22.30 & 24.66 & 20.96 \\
\hline PMA & 13.63 & 18.35 & 19.93 & 19.90 & 17.95 \\
\hline Control & 12.93 & 15.70 & 21.60 & 23.60 & 18.45 \\
\hline Mean & 11.30 & 19.17 & 21.21 & 22.42 & \\
\hline RLSD $_{0.05}$ & & level $=1.87$ & ; & atment $\mathrm{x}$ & evel $=$ ns. \\
\hline
\end{tabular}


The difference between the levels of 120 and $180 \mathrm{~kg} \mathrm{~N} \quad \mathrm{ha}^{-1}$. The nitrogen concentrations were $11.30,19.17,21.21$ and 22.42 g. $\mathrm{kg}^{-1}$ dry matter for levels $0,60,120$ and $180 \mathrm{~kg} \mathrm{~N}$. ha ${ }^{-1}$, respectively. This is in agreement with results of Jameel (2012) who indicated an increase in the concentration of nitrogen plant by increasing the level of nitrogen.

\section{Nitrogen uptake by wheat plant}

Table (4) revealed that nitrogen content of plants fertilized with urea treated with the dried aqueous extract of corn roots or urea treated with aqueous extract of corn roots were higher than plant with untreated urea, with an increase percentages of 75 and $61 \%$, respectively. However, treated urea with shoot or root powder of conocarpus did not give a significant differences as compared with untreated urea. Results of Singh \& Shivay (2003) and Haque \& Majumdar (2005) showed a significant effect of neem cake coated urea on N-uptake by rice and wheat. All urea treatments, as well as untreated urea increased the $\mathrm{N}$ uptake by wheat over the PMA treatments, with significant differences at treatment of aqueous extract and coating urea (table 4). Data presented in table (4) revealed that the increase in nitrogen rate led to an increase in the amount of nitrogen uptake with values of $9.49,40.91,63.37$ and $72.94 \mathrm{mg}$. pot $^{-1}$ for levels of $0,60,120$ and $180 \mathrm{~kg} \mathrm{~N} \cdot \mathrm{ha}^{-1}$, respectively.

The results of table (4) showed that the addition of urea treated with aqueous extract or coating at a level of $120 \mathrm{~kg} \mathrm{~N}$. ha- ${ }^{-1}$ resulted in a higher $\mathrm{N}$-uptake than that of untreated urea and urea treated with PMA at the level of $180 \mathrm{~kg} \mathrm{~N}$. ha ${ }^{-1}$ which clearly shows the possibility of reduction of $60 \mathrm{~kg} \mathrm{~N}$. ha ${ }^{-1}$. These results confirm the possible use of corn residues as an alternative to PMA.

Table (4): Effect of the methods of urea treatment on nitrogen uptake by wheat plant $\left(\mathrm{mg} \mathrm{pot}^{-1}\right)$.

\begin{tabular}{|c|c|c|c|c|c|}
\hline \multirow[t]{2}{*}{ Treatment } & \multicolumn{4}{|c|}{ Urea level $\left(\mathrm{kg} \mathrm{N} \mathrm{ha}^{-1}\right)$} & \multirow[t]{2}{*}{ Mean } \\
\hline & 0 & 60 & 120 & 180 & \\
\hline Conocarpus leaves Powder & 8.23 & 28.37 & 45.85 & 52.03 & 33.62 \\
\hline Conocarpus root powder & 5.41 & 36.04 & 63.00 & 56.06 & 40.12 \\
\hline Aqueous extract of corn roots & 11.36 & 49.12 & 81.18 & 115.50 & 64.29 \\
\hline Coated urea & 6.73 & 64.63 & 83.21 & 125.03 & 69.90 \\
\hline PMA & 14.89 & 34.99 & 67.71 & 11.16 & 32.18 \\
\hline Control & 10.34 & 32.34 & 39.31 & 77.88 & 39.96 \\
\hline Mean & 9.49 & 40.91 & 63.37 & 72.94 & \\
\hline RLSD $_{0.05}$ & 72 & $=15.06$ & & nent $\mathrm{x}$ & 36.05 \\
\hline
\end{tabular}

Similar results were obtained by Vyas et al. (1991) when he pointed out that coating urea with the extract of the neem reduced the amount of nitrogen used from $100 \mathrm{~kg} \mathrm{~N}$. ha ${ }^{-1}$ to $70 \mathrm{~kg} \mathrm{~N}$. ha ${ }^{-1}$ to give the same as the yield of the rice plant.

\section{Nitrogen recovery of wheat plant}

Table (5) explained that $\mathrm{N}$ recovery by wheat with urea treated with aqueous extract and urea coated with dried aqueous extract markedly increased compared to untreated urea. However, lower increases were recorded 
in urea treated with shoot and root powder of conocarpus. Similar results have been reported by Blaise \& Prasad (1996) and Hoshan (2012) who attributed this increase to the inhibition of urease activity and the availability of sufficient nitrogen in the soil reflected on the absorbed quantity as well as the improvement growth of the plant. As compared with PMA treatment, all treatments increased the $\mathrm{N}$ recovery by $30,62,129,190$ and $26 \%$ for treatments of shoot powder, root powder, aqueous extract, coated urea and uncoated urea, respectively (table 5).

Results showed that $\mathrm{N}$ recovery by wheat decreased by increasing urea level (table 5). At all urea levels, highest $\mathrm{N}$ recovery were obtained at treatment of coated urea with dried aqueous extract followed by treatment of urea treated with aqueous extract.

Table (5): Effect of the methods of urea treatment on nitrogen recovery of wheat plant (\%).

\begin{tabular}{lllll}
\hline \multirow{2}{*}{ Treatment } & \multicolumn{3}{c}{ Urea level $\left(\mathrm{kg} \mathrm{N} \mathrm{ha}^{-1}\right)$} & \multirow{2}{*}{ Mean } \\
\cline { 2 - 4 } & 60 & 120 & 180 & \\
\hline Conocarpus leaves Powder & 30.43 & 20.90 & 16.10 & 22.47 \\
\hline Conocarpus root powder & 33.44 & 31.99 & 18.75 & 28.06 \\
\hline Aqueous extract of corn roots & 41.95 & 38.78 & 38.56 & 39.76 \\
\hline Coated urea & 64.32 & 42.50 & 43.81 & 50.21 \\
\hline PMA & 22.33 & 29.36 & 0.32 & 17.33 \\
\hline Control & 24.44 & 16.09 & 25.01 & 21.84 \\
\hline Mean & 36.15 & 29.93 & 23.75 & \\
\hline
\end{tabular}

\section{References}

\section{Conclusion}

It can be concluded from this study that coating urea with the root extract of corn or addition of the aqueous extract of corn root with urea increased growth and uptake of nitrogen of wheat plant compared with untreated urea or treated urea with PMA, which clearly indicates the success of using corn residues as an suitable alternative to chemical inhibitor, as well as reduction of 60 $\mathrm{kg} \mathrm{N} \mathrm{ha}{ }^{-1}$ is of economic benefit and reduce the environmental risks.

\section{Acknowledgments}

We would like to thank the Department of soil sciences and water resources, College of Agriculture, University of Basrah for providing space and scientific support for this research.
Abdulkareem, M. A. (2006). Role of some plant extracts on urease activity, urea transformations in soil and barley growth. Ph. D. Thesis. Coll. Agric. Univ. Basrah: 209pp. (In Arabic).

Al-Douri ,Y.A. \& Mohammed, L. Sh. (2014). Effect of zero tillage and corn (Zea mays L.) remainders on growth characters of wheat planted lately (Triticum aestivum L.). J. Agr. Sci. Tikrit Univ., 14(3): 102115. (In Arabic).

Al-Malaky, I.A.Y \& Abdulkareem, M.A. (2018) Effect of different methods of treated-urea with plant residues on urease activity in soil. Misan J. Academic Studies-Misan Univ., In Press. (In Arabic).

Al-Mutlaq, K.F.; Al-Rajhi, D.H.; Hussein, H.I.; Ismail, M.S. \& Mostafa, S. (2001). 
Selective and toxic effect of an Alkaloidal extract from Rhazya stricta against some plants. Assiut J. Agric. Sci., 32: 6-13.

Babalar, M.; Hasan, M. \& Javad, H. (2010). Effects of nitrogen and calcium carbonate on growth, gosmarinic acid content and yield of Satureja hortensis L. J. Agric. Sci., 2(3): 92-98.

Barker, A.V. \& Bryson G.M. (2007). Nitrogen. 21-50. In: Barker, A.V. \& Pilbeam, D.J. (Eds.). Handbook of Plant Nutrition. CRC press. 129pp.

Black, C.A. (1965). Methods of Soil Analysis part II. Soc. Agron. Inc. Publ. Madison, Wisconsin: 770pp

Blaise, D. \& Prasad, R. (1996). Relative efficiency of modified urea fertilizers in wetland rice (Oryza sativa). Indian $\mathrm{J}$. Agron., 41: 373-378.

Bremner, J.M. (1982). Regular Kjeldahl Methods. 11-33 In: Page, A.L., Miller, R.H. \& Keeney, D.R. (1982). Methods of soil analysis. Part 2. 2nd ed. ASA Inc. Madison, Wisconsin: 1158pp.

Cheng, F. \& Cheng, Z. (2015). Research progress on the use of plant allelopathy in agriculture and the physiological and ecological mechanisms of allelopathy. Front. Plant Sci., 6: 1-16.

Eltelib, H.A.; Hamad, M.A. \& Ali, E.E. (2006). The effect of Nitrogen and Phosphorus fertilization on growth, yield and quality of forage maize (Zea mays L.) J. Agron., 5(3): 515-518.

FAO (2015). World fertilizer trends and out look to 2018, Rome: 53pp.

Haque, S.A. \& Majumdar, A. (2005). Efficiency of nimin-coated urea as controlled release nitrogen fertilizer on wheat. $9^{\text {th }}$ Int. Conf. East Southeast Asia Federation soil Sci. Soc.: 401-402.

Hoshan, M.N. (2012). Effect of extracts plant coated urea on urease activity and growth of barly (Hordeum vulgare L.) in salinity soils. M. Sc. Thesis. Coll. Agric. Univ. Basrah:160 pp. (In Arabic).

Jameel, D.S. (2012). Effect of treated wastewater on urea Trans Formation in soil and growth and N-Uptake of corn. M. Sc. Thesis. Coll. Agric. Univ. Basrah: 173pp. (In Arabic).

Joo, Y.K.; Christians, N.E.; Spear, G. T. \& Bremner, J.M. (1992). Evaluation of urease inhibitors as urea amendments for use on Kentucky bluegrass turf. Crop Sci., 32: 1397-1401.

Keeney, D.R. (1982). Agronomy Monograph, Methods of Soil Analysis. Part 2. Chemical and Microbiological Properties, 9.2: 711733 In Page, A.L.; Miller, R.H. \& Keeney, D.R. (Eds.) Methods of Soil Analysis Part (2). $2^{\text {nd }}$ ed. ASA. Inc. Madison, Wisconsin: $1158 \mathrm{pp}$.

Kiran, U. \& Patra, D.D. (2002). Augmenting yield and urea-nitrogen utilization efficiency in wheat through use of natural essential oils and dicyandiamide-coated urea in light-textured soils of central Uttar Pradesh. Commun. Soil Sci. Plant Analysis, 33(9 \& 19): 1375-1388.

Mathialagan, R. , Nurlidia, M. Al-Khateeb, B.; Muhammad, H.M. \& Muhammad, R.Sh. (2017). Evaluation of allicin as soil urease inhibitor. Procedia Engin., 184: 449-459.

Mohanty, S.; Patra A.K. \& Chhonkar, P.K. (2008). Neem (Azadirachta indica) kernal powder retards urease and nitrification activities in different soils at contrasting 
Al-Malaky \& Abdulkareem/ Basrah J. Agric. Sci., 32(Spec. Issue 2): 35-44, 2019

moisture and temperature regimes. Boiores. Tech., 99: 894-899.

Naseem, T.; Benjamin, S.; Senstein, J.E. \& Barzilay, R. (2009). Multilingual part-ofspeech tagging: Two unsupervised approaches. J. Artif. Intellig. Res., 36: 341385.

Neghamish, R.GH. (2012). Field Evolution of efficiency of some plants extracts and chemical inhibitors in inhibition of urease enzyme activity and growth of sorghum grop (Sorghum bicolor L.) Coll. Agric. Univ. Basrah, Ph. D. Thesis: 160pp. (In Arabic).

Nelson, D.W. \& Sommers, L.E. (1973). Determination of total nitrogen in plant material. Agron. J., 65: 109-112.

Page, A.L., Miller, R.H. \& Keeney, D.R. (1982). Methods of soil analysis. Part 2. $2^{\text {nd }}$ ed. ASA Inc. Madison, Wisconsin: 1158pp.

Patra, D. D., Kiran, U., Chand, S. \& Anwar, M. (2009). Use of urea coated with natural products to inhibit urea hydrolysis and nitrification in soil. Biol. Fertil. Soils, 45: 617-621.

Rice, E.L. (1984). Allelopathy. $2^{\text {nd }}$ ed., Academic press, Orland: 422pp.

Selim, E. M.; Elsirafy Z.M. \& Taha, A.A. (2010). Effect of irrigation methods and N application on the utilization of nitrogen by sugar beet grown under arid condition. Australian J. Basic Appl. Sci., 4(7): 21142124.

Singh, J.P. \& Singh, K. (1989). Effect of slow release nitrogen fertilizers on yield and nitrogen use efficiency in upland rice and their residual effect on wheat. Ann. Agric. Res., 10: 79- 89.
Singh, S. \& Shivay, Y.S. (2003). Coating of prilled urea with ecofriendly neem (Azadirachta indica A. Juss.) formulation for efficient nitrogen use in hyberd rice. Acta Agron. Hung., 51(1): 53-59.

Sivapalan, K.; Fernado, V. \& Thenabadu, M.W. (1983). Humified phenol-rich plant residues and soil urease activity. Plant Soil, 70: 143-146.

Trenkel, M.E. (2010). Improving fertilizer use efficiency. Controlled-release and stabilized fertilizers in agriculture. Int. Fertil. Ind. Assoc., Paris: 160pp.

Vyas, B.N.; Godrej, N.B. \& Mistry, K.B. (1991). Development and evaluation of neem extracts as a coating for urea fertilizer. Fertil. News, 36(2): 19-25.

Yaseen, Y.M. (2010) Effect of aqueous extract of rice straw on urease inhibition and growth and n- uptake of corn. M. Sc. Thesis. Coll. Agric. Univ. Basrah: 150pp. (In Arabic).

Zhao, M.; Huaibao, Z.; Qianjin, D. \& Yunfeng, S. (2015). Inhibitory effects of tropical medicinal plant extracts on urea hydrolysis and nitrification in soil: A preliminary study. Hort. Sci. China, 50(5): 744-749.

Zhu, Z.L. \& Chen, D.L. (2002). Nitrogen fertilizer use in China-Contributions to food production, environment and best management strategies. Nutr. Cycl. Agroecosys., 63: 117-127. 